\title{
Hvordan straffes der for voldtægt?
}

\author{
Af Ragnheiður Bragadóttir ${ }^{1}$
}

\begin{abstract}
During the last 30 years, there has been much debate in Iceland on sexual offences and the sanctions imposed for these offences - which have been criticised for excessive leniency. But is this criticism justified? Has it had any influence? An attempt to respond to these questions would require a survey providing a comprehensive picture of the penalties imposed and the factors determining these penalties.

The provisions on sexual offences in the Icelandic Penal Code (Act 19/1940) have undergone two major amendments: Act No. 40/1992 and Act No. 61/2007. Both acts amended the provisions on rape. Act No. 61/2007 also enacted various new provisions that influence the determination of sentences for sexual offences, including the severity of sentences in each instance. These new provisions include a broader definition of »rape", a more severe punishment for sexual crimes against children, and options for elevated sentencing in aggravated cases. It is noteworthy, however, that there are also provisions for moderated sentences and clemency in cases where the perpetrator and victim are of a similar age.

The article discusses the trends in sentences for rape imposed by the Supreme Court of Iceland in 1976-2013. The period is divided into three shorter terms following the amendments of the law, i.e. 1976-1991, 1992-2007 and 2008-2013. The provisions on rape and sentencing during each period are described. Following this, the sentences handed down in each period are analysed. Research reveals that sentences for rape committed via the use of violence or threats of violence become more severe after 2003. Meanwhile, sentences for rape committed via abuse of a victim's weaken psychological state, sleep or intoxication gradually increased in severity from the 1990s to the present. The severity in sentencing was therefore rising long before the amendments to the law. This suggests that public sentiment had an impact before the law was changed.
\end{abstract}

* Title in English: Sentences for rape. 


\section{Indledning}

I de seneste 30 år har seksualforbrydelser, lovbestemmelserne derom og sagernes behandling i retssystemet været meget i debatten i Island, både blandt forskere og borgerne alment, og den debat er endnu i gang. Denne debat har fundet sted samtidig med udviklingen i kampen for aktuel ligestilling for kvinder. Mange reformer er blevet vedtaget i denne periode. Bestemmelser i loven om offentlig retspleje blev ændret, der blev stiftet krisecenter for ofre, og politi og medarbejdere i sundhedssektoren fik oplæring og vejledning om sagernes behandling. Til sidst har straffelovens kapitel om seksualforbrydelser været revideret $\mathrm{i}$ sin helhed to gange, d.v.s. i 1992 og 2007.

Et af de emner som har været meget omdiskuteret i forbindelse med seksualforbrydelserne er den udmålte straf. Mange mener at forbrydelserne straffes for mildt og at straffen ikke er i overensstemmelse med borgernes retsbevidsthed, der kræver strengere straffe for disse forbrydelser. Undersøgelse af islændingenes holdning til straf for forskellige forbrydelser viser, at borgerne ikke har megen viden om de idømte straffe og hvilke faktorer er af betydning ved strafudmålingen. ${ }^{2}$ Det er meget vanskeligt at vurdere, hvilken straf der er passende for seksualforbrydelser. Men forudsætningen for den slags vurdering er, at det er klart, hvilken strafferamme der er for de forskellige forbrydelser, og hvilke faktorer det er, der påvirker udmålingen af straffen i de enkelte tilfælde. Man burde dog undlade at drage omfattende, almene konklusioner af enkelte domme. Derfor bør der laves en sammenfatning, som kan give et helhedsbillede af de udmålte straffe for disse forbrydelser og hvilke faktorer, der har størst vægt, når straffen fastsættes.

Denne artikel handler om straffen for voldtægt og udviklingen i Islands Højesterets strafudmåling i voldtægtssager i årene 1976-2013. ${ }^{3}$ Der skelnes der mellem tre perioder som følger ændringer i straffelovens bestemmelser om voldtægt, d.v.s. 1976-1991, 1992-2007, og til sidst fra og med 2008. For det første gøres der rede for lovbestemmelserne om voldtægt indenfor hver periode og de bestemmelser som angår udmåling af straffen, for at gøre sig klart, hvilke faktorer der spiller en rolle ved strafudmålingen. For det andet beskrives udviklingen i Højesterets strafudmåling for voldtægt i årene 1976-2013.

\section{Voldtagt ifølge straffeloven fra 1940}

1. Voldtcegt, anden ulovlig kønslig tvang og kønslig udnyttelse if. straffeloven nr. 19/1940

Den islandske straffelov er nr. 19/1940. I lovens kapitel XXII er der bestemmelser om seksualforbrydelser. Da straffeloven blev vedtaget var der tre bestemmelser i kapitlet om seksualforbrydelser, som handlede om opnåelse af samleje ved 
forskellige retsstridige midler. De var vold, trusler og anden ulovlig tvang, og udnyttelse. ${ }^{4}$ Disse bestemmelser var sålydende:

Voldtægt § 194: Den, der tvinger en kvinde til samleje ved vold eller frihedsberøvelse, eller ved at fremkalde hos hende frygt for hendes eller hendes pårørendes liv, helbred eller velfærd, straffes med fængsel mindst 1 år og indtil 16 år eller på livstid. - På samme måde straffes den, der har samleje med en kvinde ved at hensætte hende i en tilstand hvor hun er ude af stand til at modsætte sig handlingen.

Anden ulovlig kønslig tvang $§ 196$ : Den, der tvinger en kvinde til samleje ved trussel om vold, frihedsberøvelse, sigtelser om hendes strafbar eller ærerørlig optræden, eller anden omfattende ulempe, straffes med fængsel indtil 6 år, medmindre forholdet er omfattet af $\S 194$ eller $\S 195$.

Kønslig udnyttelse § 195: Den, der skaffer sig samleje uden for ægteskab, med en kvinde der er sindssyg eller mentalt retarderet, eller befinder sig i en tilstand, i hvilken hun er ude af stand til at modsætte sig handlingen eller forstå dens betydning, straffes med fængsel indtil 8 år.

Disse bestemmelser handler alle om samleje. Anden kønslig omgængelse straffedes mildere, if. straffelovens $\S 202$. Bestemmelserne var kønsbundne, således at de kun beskyttede kvinder. Det var kun dem, der kunne være ofre, og kun mænd, der kunne være gerningsmænd. Strafminimum ifølge $\S 196$ og § 195 var 30 dages fængsel.

\section{Strafudmåling}

I kapitlet om seksualforbrydelser i straffeloven fra 1940 var der ingen bestemmelser om udmåling af straffen specielt for disse forbrydelser, undtagen bestemmelsen om fakultativ strafbortfald, hvis offer og gerningsmand var ægtepar og fortsatte sit ægteskab efter forbrydelsen. Før lovændringen i 1992 var der bestemmelse om uagtsomhed i § 204 således, at hvis gerningsmanden var uagtsom $i$ henhold til ofrets mentale tilstand jf. $\S 195$, var der udmålt mildere straf.

Til gengæld er der i straffeloven mange almene regler om strafudmåling som bruges angående voldtægt, ligesom vedrørende andre forbrydelser. Der kan nævnes strafnedsættelsesgrundene forsøg i $\S 20$, stk. 2, medvirken i $\S 22$, stk. 2, og $\S 74$, der rummer en række forskellige forhold, der hjemler nedsættelse af straffen. I voldtægtssager er det især punkterne 2, 8 og 9, der har fundet anvendelse. Disse punkter vedrører alle gerningsmanden, hans alder og optræden efter forbrydelsen. Det kan f. eks. dreje sig om, at han yder erstatning, eller af egen fri vilje melder sig til politiet og aflægger fuld tilståelse. I praksis virker strafnedsættelsesgrundene næsten udelukkende formildende inden for strafferammen. I straffe- 
lovens $\S 70$ nævnes de forhold, der skal tages i betragtning ved udmåling af straffen, og som kan virke enten skærpende eller formildende indenfor bestemmelsens strafferamme. Disse forhold angår først og fremmest gerningsmanden og hans handling, men forhold, der vedrører ofret, kan dog også få betydning under de punkter, der omhandler handlingen. ${ }^{5}$

Disse almene bestemmelser bruger dommerne ved strafudmåling i sager om seksualforbrydelser. For at vise strafudmålingen i praksis gøres her rede for tre højesteretsdomme, én for hver af de tre bestemmelser. Alle dommene er fra den første periode, 1976-1991.

Voldtægt, H 1990.585: En kvinde gik hjem sammen med gerningsmanden fra en restaurant. Han blev nærgående, men hun sagde, at hun ikke ville have samleje, da hun var blevet opereret i underlivet 6 uger tidligere. Gerningsmanden gik amok og overfaldt hende. Han slog hende i ansigtet og voldtog hende. Hun sagde, at hun ville anmelde ham, men så tog han kvælertag på hende, gav hende mange lussinger og slog hende med noget, der lignede en pisk. Hun fik hævelser og skrammer. I dommen siger der, at gerningsmanden ikke er blevet straffet før og han blev idømt fængsel i 15 måneder for voldtægt if. § 194.

Anden ulovlig kønslig tvang, H 1984.1181: T havde samleje med en kvinde mod hendes vilje $\mathrm{i}$ hendes hjem. Han fik hende til samlejet med trusler, dog ikke så alvorlige at hun frygtede for sit liv, hedbred eller velfærd. Han blev idømt 12 måneders betinget fængsel med henvisning til hans unge alder, fuld tilståelse og at han ikke tidligere var straffet, og med hensyn til sagens omstændigheder.

Kønslig udnyttelse, H 1989.352: M, 47 år gammel, var tiltalt for kønslig udnyttelse ifølge $\S 195$ for at have samleje med X, 20 årig mentalt retardedet kvinde. I lægeerklæringen hed det, at X var på grænsen ved at defineres som mentalt retarderet. Først når man talte med hende forekom hun som en umoden teenager, men den som lærte hende lidt bedre at kende kunne ikke undgå at lægge mærke til at hun var betydeligt mentalt svækket. $\mathrm{M}$ påstod at han ikke var klar over pigens tilstand og i byretten var han dømt for uagtsomhed, d.v.s. straffelovens $\S 195$, jf. § 204. I Højesteret fremkom det, at $M$ havde lært $X$ at kende to år før begivenheden og derfor mente Højesteret at han havde forsæt til forbrydelsen. $\mathrm{M}$ blev straffet if. straffelovens $\S 195$ og idømt to måneders betinget fængsel.

Det er klart at i perioden 1976-1991 var den vold der anvendtes, afgørende for straffens størrelse. Såfremt der anvendtes megen vold, og der forelå andre skærpende omstændigheder eller strafforhøjelsesgrunde, kunne straffen blive indtil 4 års fængsel som var den maksimale straf, der anvendtes i praksis. Domme for anden ulovlig kønslig tvang if. $§ 196$ og kønslig udnyttelse if. $§ 195$ forekom sjældent og straffene var yderst milde, og gerne betingede. 


\section{Voldtægt ifølge lov nr. 40/1992}

1. Voldtcegt, anden ulovlig kønslig tvang og kønslig udnyttelse if. lov $n r$. 40/1992

Bestemmelserne om seksualforbrydelser i straffelovens kapitel XXII var uændrede fra 1940, helt indtil 1992, da de blev mærkbart ændret ved lov nr. 40/1992. Med loven var de tre bestemmelser, om voldtægt, anden ulovlig kønslig tvang og kønslig udnyttelse, ændret således, at sondringen mellem de tre forbrydelser blev klarere. Desuden blev bestemmelserne ændret, så at nu blev de kønsneutrale. En anden vigtigt ændring i 1992 er at anden kønslig omgængelse sidestilles med samleje. Ifølge loven fra 1992 var bestemmelsen om voldtægt sålydende (straffelovens § 194, jf. lov nr. 40/1992, § 2):

Voldtægt § 194: Den, som ved vold eller trussel om vold tiltvinger sig samleje eller anden kønslig omgængelse med en anden person, straffes med fængsel fra 1 og indtil 16 år. Til vold henregnes frihedsberøvelse ved indespærring, indgivelse af medikamenter samt andre sidestillede handlinger.

Metoden ved gerningen ifølge denne bestemmelse var vold og alle strafbare trusler om vold, men ikke andre trusler. Ifølge loven fra 1992 var bestemmelsen om anden ulovlig kønslig tvang sålydende (straffelovens $§ 195$, jf. lov nr. 40/1992, $\S 3)$ :

Anden ulovlig kønslig tvang § 195: Den, som skaffer sig samleje eller anden kønslig omgængelse med en anden person ved anden ulovlig tvang, straffes med fængsel indtil 6 år.

Når volden i § 194 fraregnes bestod forskellen i disse to bestemmelser, § 194 og $\S 195$, af de tvangsmidler der brugtes til at opnå samleje eller anden kønslig omgængelse. Blev der brugt trussel om vold blev overtrædelsen regnet for voldtægt, jf. § 194, men blev der brugt trussel om andet end vold blev overtrædelsen regnet for anden ulovlig kønslig tvang, jf. § 195. De trusler som faldt under $\S 195 \mathrm{blev}$ ikke regnet for værende så alvorlige som truslerne jf. § 194. Formålet var dog det samme i begge tilfælde, at tiltvinge sig samleje eller anden kønslig omgængelse.

Den tredje bestemmelse om forbrydelse mod kønsfriheden, d.v.s. om udnyttelse af ofrets svækkede sindstilstand for at skaffe sig samleje eller anden kønslig omgængelse, blev også ændret i 1992. Dette blev nu til § 196 (straffelovens $\S 196$, jf. lov nr. 40/1992, § 4) om kønslig udnyttelse og den var sålydende:

Kønslig udnyttelse $\S 196$ : Den, der ved udnyttelse af en persons sindssygdom eller mentale retardering skaffer sig samleje eller anden kønslig omgængelse, eller udnytter en person, der be- 
finder sig i en tilstand, i hvilken den pågældende er ude af stand til at modsætte sig handlingen eller forstå dens betydning, straffes med fængsel indtil 6 år.

Før lovændringen i 1992 var der et totalt forbud mod samleje med sindssyge og mentalt retarderede kvinder. Efter lovændringen i 1992 var samleje med sindssyge personer eller mentalt retarderede ikke strafbar, medmindre der er tale om udnyttelse, således at gerningsmanden udnytter personens svaghed for at opnå sin vilje.

\section{Strafudmåling}

Der var ingen specielle bestemmelser om strafudmåling for seksualforbrydelser i lov nr. 40/1992. De almene bestemmelser i straffeloven brugtes som før ved strafudmålingen. Domme for anden ulovlig kønslig tvang var ydest få og der har i virkeligheden aldrig været tilfælde, hvor det har været relevant at dømme ifølge $\S 195$ om anden ulovlig kønslig tvang.

For at vise strafudmålingen i praksis i den anden periode, 1992-2007, gøres her rede for tre højesteretsdomme, én for hver af de tre bestemmelser.

Voldtægt, H 1999.3459: En 16 årig pige gik med aviser i et boligkvarter tidligt om morgenen. Tiltalte kom ind i en opgang hvor hun satte aviser i postkasser, befamlede hende, forhindrede hende $\mathrm{i}$ at komme ud, overfaldt hende og havde samleje med hende. Han var ikke tidligere straffet og i betragtning af pigens unge alder og de øvrige omstændigheder blev straffen udmålt til 2 års fængsel.

Anden ulovlig kønslig tvang, H 1996.2910: M, 49 år, blev tiltalt for med ulovlig tvang at have tvunget en 16 årig pige, A, til samleje eller anden kønslig omgængelse. I tiltalen blev overtrædelsen anset for at henhøre under straffelovens $\S 195$ og tiltalte fandtes skyldig i byretten. Afgørelsen blev bekræftet i Højesteret. $\mathrm{M}$ havde inviteret $\mathrm{A}$ med på en ridetur og de tog sammen $\mathrm{i}$ hans bil til en hestestald, der lå fjernt fra bebyggede områder. Der gik de ind i laden og havde samleje. Det fremkom at A var $158 \mathrm{~cm}$ høj og $47 \mathrm{~kg}$ tung, medens M vejede $90 \mathrm{~kg}$ og var 170-180 cm høj. M nægtede først at have haft samleje med A, men erkendte senere og sagde, at det foregik med As samtykke. Det var rettens vurdering, at det ikke var betænkeligt at anse for bevist, at tiltalte i den givne situation havde gjort brug af sin overlegenhed og tvunget ofret til samleje. Straffen blev udmålt til 12 måneders fængsel med hensyn til pigens unge alder og forbrydelsens karakter.

Kønslig udnyttelse, H 2. maj 2002 (nr. 52/2002): En kvinde tog sammen med sin veninde på en restaurant, hvor hun blev halvt bevidstløs af beruselse. Hendes venner kørte hende hjem i taxa om natten og hjalp hende i seng, hvor hun faldt $\mathrm{i}$ søvn. De kunne ikke låse lejligheden eftersom den kun kunne låses udvendigt 
med en nøgle. Efter at taxachaufføren, M, havde kørt vennerne hjem, vendte han tilbage til kvindens hjem. Han gik ind til hende uden tilladelse, lagde sig ovenpå hende, befamlede hende og satte en finger ind i hendes kønsdele. Han udnyttede på denne måde at hun ikke kunne modsætte sig forbrydelsen på grund af beruselse og søvn. Det var af betydning ved strafudmålingen at $\mathrm{M}$ også var dømt for at trænge sig ind i kvindens hjem og det var strafskærpende at han udnyttede sin viden om hendes tilstand som han fik i sit arbejde som taxachauffør. Straffen blev sat til 18 måneders fængsel.

Hvis man ser på disse domsafgørelser ser den udmålte straf for voldtægt i perioden 1992-2007 ikke ud til at være meget anderledes end i perioden 1976-1991. Straffen for kønslig udnyttelse er til gengæld blevet strengere. Men man må se på flere domme for bedre at kunne se udviklingen i strafudmålingen.

\section{Voldtægt ifølge lov nr. 61/2007}

\section{1. Én bestemmelse om voldtcegt, if. lov $n r$. 61/2007}

Ved lov nr. 61/2007 blev størstedelen af straffelovens kapitel om seksualforbrydelser revideret med det princip for øje, at øge kvinders og børns retsbeskyttelse. ${ }^{6}$ Blandt nyheder i loven fra 2007 er der bestemmelser, der har indflydelse på strafudmåling for seksualforbrydelser og derved den straf, der udmåles hver gang. Én af de vigtigste ændringer er at begrebet voldtægt er blevet udvidet meget. Før lovændringen var samleje eller anden kønslig omgængelse mod ofrets vilje ikke voldtægt, medmindre der anvendtes vold eller trusler om vold, som beskrevet her foran. Nu er der ikke længere den store vægt på forbrydelsens midler, og tyngdepunktet ligger på, at der med forbrydelserne bliver gennemført samleje eller anden kønslig omgængelse med ofret uden vedkommendes samtykke.

Begrebet voldtægt er nu defineret i selve lovbestemmelsen, jfr. straffelovens $\S 194$. Anden ulovlig tvang (den ældre $\S 195$ ) og udnyttelse af ofrets svækkede sindstilstand, eller at ofret befinder sig i en tilstand, i hvilken den pågældende er ude af stand til at modsætte sig handlingen eller forstå dens betydning (den ældre $\S 196)$ defineres nu som voldtægt. Strafniveauet for disse forbrydelser er derfor blevet forhøjet meget i forhold til tidligere, til fængsel fra 1 år og indtil 16 år, i stedet for fængsel indtil 6 år.

Den ældre $\S 195$ om andre trusler end trusler om vold ved at opnå samleje anvendtes meget sjældent i praksis. I de få domme der findes udnyttede gerningsmanden sin overlegenhed for at tvinge ofret til samleje, en opførsel der kunne været faldet under $\S 194$ om voldtægt som trussel om at udøve vold. Derfor anså man ved revideringen af lovbestemmelserne, at der ikke var grund til at skelne mellem trussel om vold og andre trusler. ${ }^{7}$ 
Der er faldet betydeligt flere domme for overtrædelse af straffelovens $\S 196$ (se nu gerningsbeskrivelse i $\S 194$, stk. 2) i de seneste år. Det drejer sig om alvorlige forbrydelser, der indebærer en stor uret overfor ofret, men blev dog ikke anset for at være voldtægt før lovændringen i 2007. Disse forbrydelser er nu defineret i loven som voldtægt og straffes som anden voldtægt, d.v.s. med fængsel fra 1 år og indtil 16 år, i stedet for 30 dage indtil 6 års fængsel før lovændringen. ${ }^{8} \mathrm{Be}-$ stemmelsen i straffelovens $\S 194$ fordeles nu på to stykker. Stk. 1 omhandler voldtægter der er sket ved vold eller trusler og nu er indholdet af truslen ikke afgørende. I stk. 2 er der bestemmelse om voldtægt der sker ved udnyttelse af ofrets sårbare stilling.

Den nugældende bestemmelse om voldtægt er sålydende:

$\S 194$, stk. 1. Den, som med vold, trusler eller anden ulovlig tvang har samleje eller anden kønslig omgængelse med en anden person er skyldig i voldtægt og straffes med fængsel fra 1 og indtil 16 år. Til vold henregnes frihedsberøvelse ved indespærring, indgivelse af medikamenter samt andre sidestillede handlinger.

§ 194, stk. 2. Det er også voldtægt og straffes på samme måde som i stk. 1, at udnytte en persons sindssygdom eller mentale retardering til at skaffe sig samleje eller anden kønslig omgængelse, eller at udnytte en person, der befinder sig i en tilstand, i hvilken den pågældende er ude af stand til at modsætte sig handlingen eller forstå dens betydning.

\section{Strafudmåling}

Med lov nr. 61/2007 blev der lovfæstet nogle bestemmelser som er af betydning ved udmåling af straf for voldtægt. Således blev der lovfæstet en ny bestemmelse i straffelovens $\S 195$ om tre punkter til strafskærpelse ved udmåling af straf for voldtægt, i tillæg til straffelovens almene bestemmelser derom. Det første er, at det skal tjene til strafskærpelse, hvis ofret er et barn under 18 år. Med denne bestemmelse lægges der vægt på, hvor alvorlige og forkastelige seksualforbrydelser mod børn er. Det næste er, at det skal tjene til strafskærpelse, hvis gerningsmandens vold er grov. Det sidste er om strafskærpelse, hvis forbrydelsen sker på en særlig smertefuld eller krænkende måde. Forbilledet for denne bestemmelse er en tilsvarende bestemmelse i den norske straffelov. ${ }^{9}$

Der er blevet lovfæstet i straffelovens $\S 205$ bestemmelser om forhøjet straf i gentagelsestilfælde, hvor straffen bliver skærpet med op til $50 \%$. Men eftersom strafmaksimum i bestemmelserne om seksualforbrydelser for det meste er høj, og at det er sædvane $\mathrm{i}$ islandsk ret at fastsætte straffen nederst inden for de enkelte bestemmelsers strafferamme, vil denne gentagelsesbestemmelse i virkeligheden 
først og fremmest virke til strafskærpelse inden for strafferammen for de enkelte seksualforbrydelser.

Der er blevet lovfæstet en ny hjemmel i $§ 202$, stk. 1, for strafnedsættelse eller strafbortfald, når den, som er skyldig i en forbrydelse mod et barn under 15 år, er jævnbyrdig med barnet i alder og udvikling. ${ }^{10}$

For at vise strafudmålingen i praksis i den tredje periode, fra 2008 til dags dato, gøres her rede for to højesteretsdomme, én for hvert af de to stk. i den nugældende bestemmelse om voldtægt.

H 9. december 2010 (nr. 555/2010): Kvinden mødte gerningsmanden, som hun ikke kendte i forvejen, i byen ved nattetid, og gik sammen med ham til hans hjem for at bruge hans telefon. Der skubbede han hende så hun faldt, blev fortumlet og fik hævelser på pande og kind. Han holdt hendes arme op langs hendes hoved og havde samleje med hende mod hendes vilje. Han nægtede at have haft samleje med kvinden, men DNA undersøgelser viste det modsatte. Han blev fundet skyldig for voldtægt ifølge $\S 194$, stk. 1. Ved strafudmålingen er der henvist til 1., 2. og 6. led, stk. 1. § 70, bl.a. på grund af de skader kvinden var udsat for, og straffen blev fastsat til fængsel i 3 år og 6 måneder.

H 1. november 2012 (nr. 354/2012): Gerningsmanden og kvinden kendte hinanden i forvejen og mødtes til en fest. Han havde samleje med hende i sit hjem, da hun sov og ikke kunne modsætte sig handlingen på grund af beruselse og søvn. Han blev fundet skyldig i voldtægt ifølge $\S 194$, stk. 2. Han var ikke tidligere straffet og med hensyn til 1. led, stk. $1 . \S 70$ om forbrydelsens grovhed blev straffen sat til 2 års fængsel.

Det fremgår af disse domme at der er sket en forhøjelse af straffene for voldtægt, både den som er udført med vold og trusler, og udnyttelse.

\section{Strafudmåling for voldtægt 1976-2013}

Undersøgelse af domme i Island er besværlig. Landets befolkning er ikke stor, kriminaliteten er lav og dommene derfor få. Domme for seksualforbrydelser er så få, at det er svært at drage statistiske konklusioner om, hvorvidt straffene har ændret sig i perioden 1976-2013. Men jeg har dels kunnet undgå dette ved at lave en figur over domme, undersøge hver enkelt dom og sammenligne dem.

Behandlingen af straf for voldtægt bliver delt op i to dele. Først bliver der gjort rede for voldtægt, der sker med vold eller trussel derom, jf. § 194, stk. 1 . $^{11}$ Siden omhandles voldtægt, der sker ved udnyttelse af ofrets mentale retardering, beruselse eller søvn, jf. § 194, stk. 2. Denne inddeling lægges som grundlag, da der kun er gået 6 år, siden ændringsloven nr. 61/2007 trådte i kraft. Det er endvidere interessant at se den forskel, der var på idømte straffedomme afhængigt af, 
hvilken metode der blev anvendt ved forbrydelsen. Hvis tiltalte er idømt straf både ifølge stk. 1 og $2, \S 194$, grupperes dommen under $\S 194$, stk. 1 .

\section{Vold eller trussel om vold}

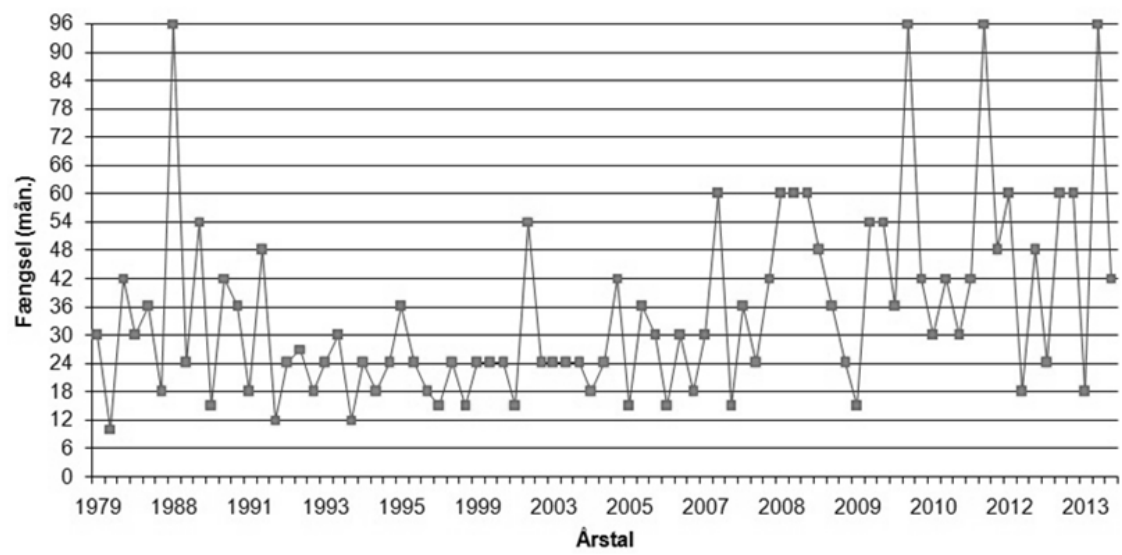

Figur 1. Straffor voldtcegt (vold eller trussel om vold) 1976-2013

I perioden 1976-2013 blev der afsagt 85 domme i Højesteret, hvor der blev dømt for voldtægt, der blev udført med vold eller trussel derom. Straffen i 81 af disse domme vises her på figur 1 . Hvis flere end én gerningsmand blev dømt i samme sag, viser figuren kun straf for en af dem, og da den, som fik den hårdeste dom. På figuren udelades der fire domme, da der også blev dømt for andre alvorlige forbrydelser, der var afgørende for strafudmålingen. ${ }^{12}$

Det er af interesse at dele disse 38 år, som figuren omfatter, op i tre perioder, som nogenlunde følger lovændringerne. Den første periode er 1976-1992, d.v.s. 17 år. Da blev der fældet 19 straffedomme. Deraf vises 17 på figuren. Den anden periode, 1993-2007, er 15 år. Da blev der fældet 39 straffedomme, hvoraf 37 vises på figuren. Den sidste periode er årene 2008-medio 2013, d.v.s. 5,5 år. Da blev der fældet 27 straffedomme. Af dette kan man se, at antallet af domme stiger meget. I den første periode blev der fældet godt 1 dom i gennemsnit om året, i den anden periode knap 2 domme $\mathrm{i}$ gennemsnit om året, men i den sidste periode er de i gennemsnit 4,9 per år.

I den første periode er dommene meget forskellige. I 8 domme er straffen mindre end 2 1/2 års fængsel, d.v.s. mindre end 30 måneder. Deraf er straffen 12 
til 24 måneder i 6 domme. I 9 domme er straffen 30 måneders fængsel eller mere. Deraf er der 6 domme med straffen 30-42 måneders fængsel. I gennemsnit er straffen 33 måneders fængsel, men hvis man ser bort fra den hårdeste dom, med 8 års fængsel, ville straffen i gennemsnit være 29 måneders fængsel.

I den anden periode, 1993-2007, er strafudmålingen betydelig mere homogen end i den første periode, især indtil 2003. I årene 1993-2003 er straffen 1-3 års fængsel i alle tilfælde, undtagen ét. Der kan man også se en klar normalværdi (= den mest almindelige straf), d.v.s. 2 års fængsel. Den strafudmåling bliver anvendt i mere en halvdelen af dommene, 12 domme ud af 23, og straffen er i gennemsnit 23 måneders fængsel, halvt år mildere end i den første periode. I årene 2004-2007 er straffen i gennemsnit 30 måneders fængsel, d.v.s. den samme som i den første periode og straffen er begyndt at svinge igen.

Den tredje periode, ligesom den første periode og sidste halvdel af den anden, bærer præg af meget forskellig strafudmåling og dommene fortsætter med at blive hårdere. Ud af 27 domme er straffen 2 til 5 års fængsel i 21 domme. I 3 domme er straffen mindre en 2 års fængsel og i 3 domme er straffen mere end 5 års fængsel. I gennemsnit er straffen godt 4 års fængsel.

Dommene i den første periode er så få, at det er svært at drage almene konklusioner om strafudmålingen. Det er dog klart at den udøvede vold er helt afgørende om straffens størrelse. Det er sikkert også forklaringen på at straffene er mildere i den anden periode end den første, fordi stigning i antal domme er først og fremmest i sager hvor der er anvendt mindre vold og derfor bliver gennemsnitsstraffen mildere og mere homogen. En sammenligning af beskrivelse af hændelsesforløbet i domme fra den anden og den tredje periode viser, at hårdere domme i den tredje periode ikke kun kan forklares med, at forbrydelserne er grovere. Straffen nu ser ud til at være hårdere end før for lignende forbrydelser, bl.a. fordi domstolene i større omfang ser ud til at være begyndt at udnytte strafferammen og lægger mere vægt på forbrydelsen mod kønsfriheden.

\section{Udnyttelse af mentalt retarderede, sovende eller berusede mennesker} Inden kapitlet om seksualforbrydelser blev ændret i 2007, var strafferammen for samleje med et mentalt retarderet, sovende eller beruset menneske fra fængsel i 30 dage og indtil 6 år, jf. loven fra 1992, men indtil 8 år if. loven fra 1940. Straffen udmåltes $\mathrm{i}$ den nederste del af strafferammen ifølge sædvane $\mathrm{i}$ islandsk ret. Inden 2002 oversteg den ikke 12 måneders fængsel. En undtagelse herfra er en højesteretsdom fra året $1995 .^{13}$ 


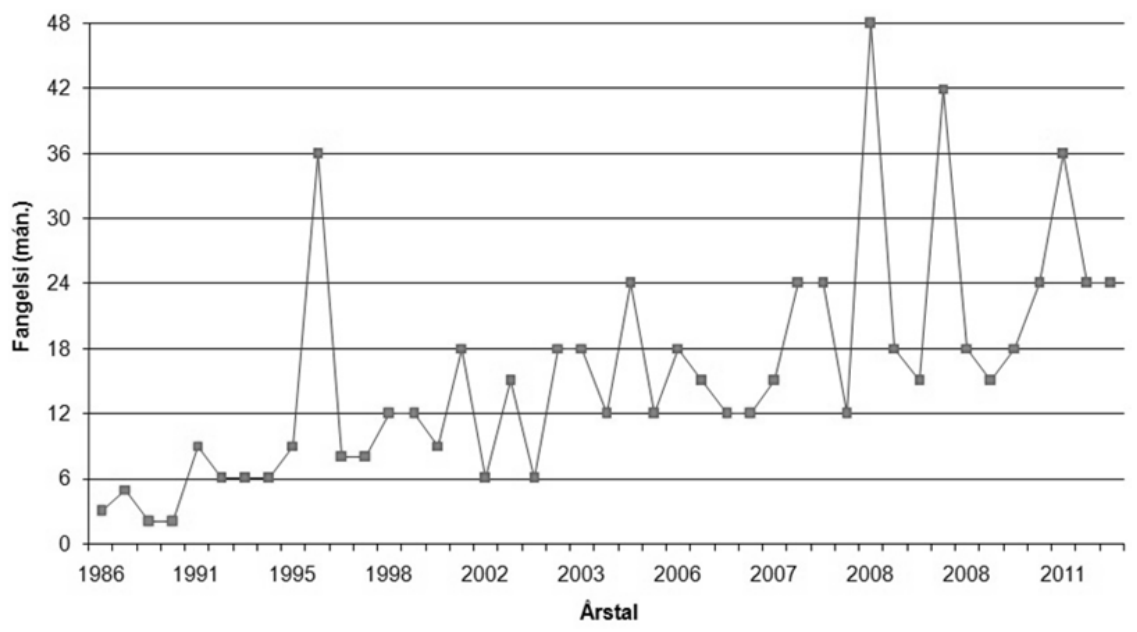

Figur 2. Straf for voldtcegt (mental retardering, søvn og beruselse) 1976-2013

I perioden, som behandles her, er der 43 straffedomme. Dommene er steget betragteligt. I perioden 1976-2001 bliver der afsagt 0-2 domme om året. Ialt er der faldet 15 domme på disse 26 år, d.v.s. i gennemsnit 0,6 domme om året. I en 12 årig periode 2002-medio 2013, falder der 28 domme eller i gennemsnit 2,4 om året. Figuren viser, at straffene også stiger kraftigt. I 1976-1985 er der ingen domme. I 1986-1990 er der nogle få med meget milde straffe, oftest betingede. I 1991-1995 er der nogle domme med straf 6 til 9 måneders fængsel. I 1996-2000 er straffen steget til 8 til 12 måneder, i 2001-2005 til 14 måneder i gennemsnit og i 2006-2010 til 24 måneder i gennemsnit.

I hele perioden er straffene for disse forbrydelser blevet hårdere, og det er interessant at lægge mærke til, at dette sker inden lovændringen i 2007, og inden bestemmelserne om disse forbrydelser bliver ændret i den retning, at de nu blev regnet for voldtægt. I de seneste tre år er straffen fængsel i 1 år og 6 måneder til 3 år. Det ser derfor ud til at straffen i dommene for denne forbrydelse nu ligger tæt på 2 års fængsel. De nærmer sig derfor åbenbart strafudmålingen for voldtægt, hvor der anvendes mild vold eller trussel om vold. 


\section{Konklusion}

Antallet af straffedomme stiger hastigt, fra ingen dom i de første år til 4,9 (voldtægt der sker ved vold eller trussel derom) og 2,4 (voldtægt der sker ved udnyttelse af ofrets mentale retardering, beruselse eller søvn) om året.

Ved at stille dommenes konklusioner op i en figur, undersøge hver dom og sammenligne dem kan man se en bestemt udvikling i den retning at straffene for disse seksualforbrydelser er blevet hårdere. For seksualforbrydelser mod mentalt retarderede, sovende eller berusede er straffene støt og roligt blevet hårdere i den periode, som her er til belysning. Ved voldtægt, der bliver begået med vold eller trussel om vold, bemærker man især en ændring til strafskærpelse efter året 2003. Jeg mener at omkring dette tidspunkt er dommerne blevet opmærksomme på, at det hvor alvorlig en voldtægtsforbrydelse er, ikke kun er afhængigt af den anvendte vold eller metode. Det som er mest alvorligt ved voldtægt er forbrydelsen mod kønsfriheden. Det er bemærkelsesværdigt, at samfundets ønsker i de seneste 20 år om hårdere straffe for seksualforbrydelser havde indflydelse længe inden loven blev ændret i 2007, således at man kan sige, at lovændringen til en vis grad har været en bekræftelse af den udvikling, som allerede havde fundet sted.

Men hvorfor bliver dommene flere og hårdere før loven blev ændret i 2007 ? Der mener jeg at diskussionen i samfundet, både blandt borgerne og forskere, har haft stor betydning. I de seneste 20 år er der forsket meget indenfor området og den videnskabelige forskning og debat har dannet grobund for det videre arbejde. De forskellige idealistiske gruppers og interesseorganisationers kamp har på denne måde fået forskningsmiljøets støtte, hvilket har givet deres kamp øget vægt og bekræftet, at deres kritik af lovgivning og praksis hviler på et solidt grundlag. Denne debat og øget viden fører til at flere ofre anmelder forbrydelser og derfor kommer flere sager op i gennem retssystemet. Diskussionen og ny viden har inflydelse på dommerne og det er af afgørende betydning at flere kvinder er blevet dommere i Højesteret, herunder én med megen viden og erfaring som dommer i disse sager.

\section{Noter}

1. Ragnheiður Bragadóttir er professor ved det Juridiske Fakultet, Islands Universitet.

2. Se debat om holdninger til straf bl.a. hos Helgi Gunnlaugsson: Afbrot á Íslandi (Forbrydelser i Island) (2008) og samme: Vil offentligheden i Island have strengere straffe end domstolene? NSfKs 53. forskerseminar, Balingsholm, Sverige (2011).

3. I de sidste 15 år har jeg forsket i straffelovens bestemmelser om seksualforbrydelser, både selve lovgivningen såvel som dens anvendelse. Jeg har offentliggjort resultatet af mine undersøgelser i forskellige videnskabelige tidsskrifter og bøger. For 15 år siden oprettede jeg et nyt kursusfag ved det juridiske fakultet ved Islands Universitet sammen med docent Bryn- 
hildur G. Flóvenz. Kurset fik navnet Voldsforbrydelser i kvinderetligt perspektiv. I 20052006 lavede jeg et udkast til lovforslag til ændring af straffelovens kapitel om seksualforbrydelser og det byggede bl.a. på den forskning jeg havde arbejdet med. Forslaget blev til lov nr. 61/2007. Alt dette arbejde ligger til grund for nærværende forelæsning og i førnævnte værker henvises der til de primære kilder som de er baseret på.

4. Der fandtes også andre bestemmelser om forbrydelser mod kønsfriheden, f. eks. udnyttelse af specielle fortrolighedsforhold og at tilsnige sig samleje, men de er ikke af betydning her og anvendtes meget sjældent af domstolene.

5. Jonatan Thormundsson: Viðurlög við afbrotum (Sanktioner mod forbrydelser). Bókaútgáfa Orators, Reykjavík 1992, s. 255.

6. Ændringerne behandles i: Ragnheiður Bragadóttir: Seksualforbrydelser - Forslag til ændring af den islandske straffelov. Nordisk Tidsskrift for Kriminalvidenskab, nr. 2 august 2006. På det islandske indenrigsministeriums webside kan man se straffeloven i dansk oversættelse: http://www.innanrikisraduneyti.is/log-og-reglugerdir/thydingar/nr/837

7. Om trussel ifølge den ældre lovs $\S 195$ som en metode til at opnå samleje henvises til min artikel: Vold eller ulovlig tvang? - om voldtægt i islandsk ret. I: Jurist uden omsvøb, Festskrift til Gorm Toftegaard Nielsen. Red.: Annette Møller-Sørensen og Anette Storgaard. Christian Ejlers' Forlag. København 2007.

8. Ragnheiður Bragadóttir: List og vold - Nyt voldtægtsbegreb i den islandske straffelov. NSfK's Research Seminar, Djurönäset, Sweden 2007.

9. Alpt. (Altingstidende) 2006-2007, A-deild (A-afdeling), s. 556 og Ragnheiður Bragadóttir: Kynferðisbrot (Seksualforbrydelser) (2006), s. 142.

10. Alpt. (Altingstidende) 2006-2007, A-deild (A-afdeling), s. 560 og Ragnheiður Bragadóttir: Kynferðisbrot (Seksualforbrydelser) (2006), s. 147-148.

11. Ragnheiður Bragadóttir: Ákvörðun refsingar í nauðgunarmálum. (Strafudmåling i voldtægtssager) Úlfljótur, 1. nr. 1999, s. 67-84, Refsingar í nauðgunarmálum. (Straffe i voldtægtssager) Rannsóknir í félagsvísindum IV. Lagadeild. Félagsvísindastofnun Háskóla Íslands 2003, s. 29-44 og Udviklingen i strafudmåling for seksualforbrydelser, Liber amicarum et amicorum Karin Cornils - Glimt af nordisk straffrätt og straffeprosessrett 2010, s. 5975.

12. I den første dom, H 1980.89, var straffen 13 års fængsel for bl.a. voldtægt, legemsangreb med døden til følge og brandstiftelse. I den anden dom, H 1983.1608, var straffen 10 års fængsel for alvorlig legemsbeskadigelse, faredelikt og forsøg på voldtægt. I den tredje dom, H 1993.1947, var straffen 12 års fængsel, men her drejede det sig om to voldtægter, legemsbeskadigelse og røveri. I den fjerde dom, H 2001.2091, var straffen 18 års fængsel for manddrab, to voldtægter og legemsbeskadigelse.

13. H 1995.2351. Tiltalte blev idømt 3 års fængsel for forsøg på overtrædelse af $\S 196$ over for en mentalt retarderet mand, som var $75 \%$ invalid. Her drejede det sig envidere om frihedsberøvelse, foruden at der blev set på den tiltaltes kriminelle løbebane, jf. straffelovens $\S 72$, men han var 28 gange blevet dømt for forskellige forbrydelser, derunder seks gange for seksualforbrydelser mod børn og unge. 